UCRL-ID-135929

\title{
Trafficking of Nuclear Materials from the Former Soviet Union: News Abstracts
}

\author{
T.M. Lawson, S.A. Erickson
}

August 31, 1999

U.S. Department of Energy

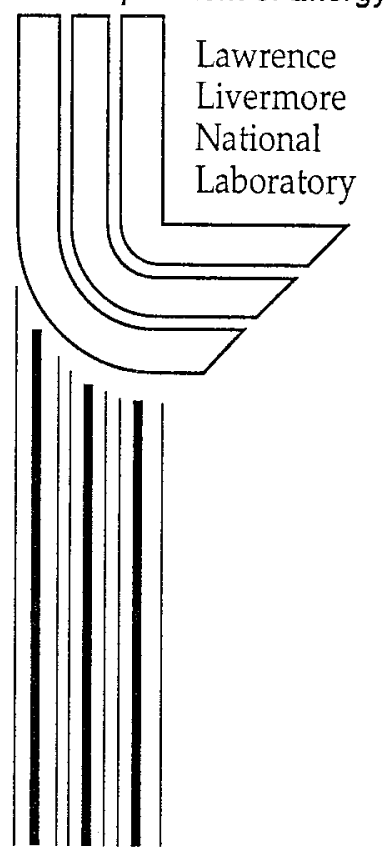




\section{DISCLAIMER}

This document was prepared as an account of work sponsored by an agency of the United States Government. Neither the United States Government nor the University of California nor any of their employees, makes any warranty, express or implied, or assumes any legal liability or responsibility for the accuracy, completeness, or usefulness of any information, apparatus, product, or process disclosed, or represents that its use would not infringe privately owned rights. Reference herein to any specific commercial product, process, or service by trade name, trademark, manufacturer, or otherwise, does not necessarily constitute or imply its endorsement, recommendation, or favoring by the United States Government or the University of California. The views and opinions of authors expressed herein do not necessarily state or reflect those of the United States Government or the University of California, and shall not be used for advertising or product endorsement purposes.

This report has been reproduced directly from the best available copy.

Available to DOE and DOE contractors from the Office of Scientific and Technical Information

P.O. Box 62, Oak Ridge, TN 37831

Prices available from (615) 576-8401, FTS 626-8401

Available to the public from the

National Technical Information Service

U.S. Department of Commerce

5285 Port Royal Rd.,

Springfield, VA 22161 
Trafficking of Nuclear Materials From the Former Soviet Union: News Abstracts

Taken from the NIS Nonproliferation Project at the Center for Nonproliferation Studies, MIIS

Tiffany M. Lawson, L awrence I ivermore National Laboratory

PO Box 808; L-175 Livermore, CA 94551

Telephone: 925/422-2996 FAX: 925/422-9292<lawson18@1lnl.gov>

Stanley A. Erickson, Lawrence Livermore National Laboratory

PO Box 808; L-181 Livermore, CA 94551

Telephone: 925/422-6548 FAX: 925/422-8471 <serickson@1lnl.gov>

\begin{abstract}
:
This report was generated to provide a background for understanding the type and variety of smuggling incidents that have been reported. As discussed in the Site Prioritization report, smuggling cases provide insight into the activities of what has been called "amateur smuggling", that is, smugglers who do not belong to a professional smuggling gang. In many instances, the law enforcement officials giving the press relcase are not familiar with nuclear matcrials, and give incorrect identification. The other portions of the information, such as number of individuals involved, places, and modes of operation are likely to be more correct.
\end{abstract}

05/14/99 - VECHERNIY BISHKEK, "ChP v aeroportu [Emergency Situtation at the Airport]," by Yu Gruzdov.

On 14 May 1999 Kyrgyzstani security agents at Manas airport, outside Bishkek, arrested an Uzbek national who was trying to smuggle a capsule of radioactive material onto a flight to the United Arab Emirates. The smuggler, identified as Takhir Naizov, was carrying the material in a metal capsule wrapped in rubber in his pocket. The guards checked the capsule with a dosimeter which indicated that it was emitting fatal doses of radiation at close range. Naizov told police that he had agreed to carry the capsule in exchange for $\$ 16,000$. He had received the capsule at the airport from an unidentified man and believed that he was carrying plutonium although the substance was not identified.

05/22/99 - FBIS Document FTS19990524001533. "Ukrainian Authorities Arrest Four Armenians Selling Russian Uranium," by Yaroslav Halas.

Ukrainian authorities on 19 May 1999 arrested four Russian citizens who were attempting to smuggle 20kg of "enriched uranium ore" to Western Europe. Colonel Vasyl Vartsaba, head of the Transcarpathian directorate for fighting organized crime, said that the suspects, residents of the Krasnoyarsk and Stavropol regions of Russia, had brought the uranium to Ukraine in December 1998 , to sell it for $\$ 60,000 / \mathrm{kg}$, which would have netted them $\$ 1.2$ million, but later reduced their asking price to $\$ 35,000 / \mathrm{kg}$. The level of enrichment was not specified. According to the report, the uranium "is known to have been stolen at a radioactive materials recycling facility in Krasnoyarsk. If this report is accurate, the facility involved is probably the Mining 
and Chemical Combine in Zheleznogorsk (formerly known as Krasnoyarsk-26), which is located in Krasnoyarsk Kray.

3/18/99 - AL-NAHAR (Beirut), "Lebanese Trying to Sell Uranium to Iran Reportedly Caught," by Bahjat Jabir; in FBIS Document FTS19990318001196.

Lebanese security agents have arrested two men, Fu'ad Abduh al-Shuwayri and Butrus Michael Najim, who were allegedly attempting to sell $6 \mathrm{~kg}$ of uranium to Syrian nationals with close connections to Iran for $\$ 210$ million.

3/1/99 - INTERNATIONAL POLICE REVIEW, (March-April 1999), "The Trade In Materials for Weapons of Mass Destruction," by Ali M. Koknar, pp. 24-25.

In July 1994, Turkish authorities arrested seven Turkish citizens and confiscated 12kg of uranium, which reportedly came from Azerbaijan. The uranium was later determined to be "weapons grade."

In September 1998, Turkish police arrested nine suspects and confiscated $4.5 \mathrm{~kg}$ of unprocessed uranium and $6 \mathrm{~g}$ of plutonium. However, in October 1998, the head of the Turkish Atomic Energy Authority denied that any plutonium had been involved in this case.

1/13/99 - PHILADELPHIA INQUIRER, "Bumbling Gang Took Gray for Gold," by Jeffrey Fleishman, <http://www.phillynews.com/inquirer/99/Jan/10/front_page> In December 1994, $2.72 \mathrm{~kg}$ of HEU was seized from a group of smugglers in the capital of the Czech Republic. The three smugglers who were convicted in the case, Aleksandr Sherbinin, Zdenech Cech, and Joseph Vagner, skipped bail in April 1998. As of January 1999, none of the three have been taken back into custody.

Among the possible buyers the group unsuccessfully negotiated with were Germans, who demanded a certificate of authenticity for the material, Nigerians, who wanted to trade drugs for the uranium, and Italians, who were willing to pay five times the asking price for the uranium, but only in counterfeit currency.

1/12/99 - PHILADELPHIA INQUIRER, "Sting Unravels Stunning Mafia Plot," by Jeffrey Fleishman, <http://www.phillynews.com/inquirer/99/Jan/12/front_page/>

In March 1998 a sting operation code named "Operation Gamma" by Italian police led to the seizure of a $190 \mathrm{~g}$ bar of HEU from Italian mafia members. The HEU bar, a fuel rod from a USdesigned research reactor containing uranium enriched to 20 percent U-235 had been diverted from a facility in Zaire probably during the 1997 overthrow of Mobutu Sese Seko. Police believe that the HEU bar they seized is only one of eight the mafia groups were marketing for a suggested price of $\$ 112$ million; the other seven--weighing $1.3 \mathrm{~kg}$--are probably still hidden somewhere in Italy.

On examination, the HEU rod turned out to be a fuel rod from the TRIGA II research reactor. The rod, numbered 6916, was manufactured by General Atomic in San Diego in 1971, and shipped to Zaire in 1997. It was one of at least 10 such bars shipped to Zaire by the United States under the Atoms for Peace program. The Triga II reactor, built in 1972, was shut down in 1992 
when the United States refused to sell any more spare parts to Zaire. The IAEA had noted in the 1980s that some uranium was missing from the reactor, but it is believed by Italian investigators that the rod involved in this case was not diverted until September 1997, possibly carried in a diplomatic pouch by part of then-President Mobutu's entourage when the former dictator escaped from Zaire.

12/10/98 - TRIBUNA (Syktyvkar), "Prodat uran ne udalos," by Vladimir Rhyzkov; in WPS YADERNIY MATERIALY, No. 39, 21 December 1998

According to this report in Tribuna, a newspaper published in Syktyvkar, the capital of the Komi Republic in Russia, four inhabitants of Ust-Kamenogorsk, Kazakhstan, were arrested after attempting to sell $7 \mathrm{~kg}$ of uranium (enrichment level unspecified) to unnamed buyers in the United States. The unidentified smugglers reportedly wanted $\$ 408,000$ for the uranium. The same article also reports another incident in which another group of smugglers tried to sell $2 \mathrm{~kg}$ of uranium (enrichment level also unspecified).

9/25/98 - THE FRONTIER POST (Peshawar), 24 September 1998, p. 1; in "Pakistani Police Seize Uranium from Arrested Afghans," FBIS Document FTS19980924000412 According to The Frontier Post, Peshawar police arrested two Afghani nationals during a Nasirbagh refugee camp raid. Eight to ten kilograms of uranium were recovered from the suspects, identified as Mujahid Khan and Ghulam Hazrat. Khan and Hazrat were in the process of selling the uranium, reportedly brought from Kazakhstan, to a foreign party for $\$ 100,000$.

9/7/98 - ANATOLIA (Ankara); in "Eight Persons Caught Smuggling Nuclear Materials," in FBIS Document FTS19980907001060.

The Istanbul Finance and Customs Department announced on 7 September 1998 that its agents had arrested eight people on suspicion of smuggling nuclear materials from Russia. Following a "sting" operation, police arrested the eight suspects and seized $4.5 \mathrm{~kg}$ of "nonactive" solid uranium and $6 \mathrm{~g}$ of "active" plutonium. Turkish officials said the materials could be used to make nuclear weapons, although they did not specify the level of enrichment of the seized uranium. The police told journalists that the had tried to sell the nuclear materials for $\$ 1$ million.

6/18/98 - ANS TELEVISION NETWORK (Baku); in "Azeri Security Ministry Thwarts Sale of Stolen Cesium," FBIS-SOV-98-171.

Tofig Babayev, an official of the National Security Ministry of Azerbaijan said that his agency had thwarted an attempt by employees of the Sumgait Aluminum Factory to sell radioactive cesium. Babayev said that agents of the National Security Ministry, acting on a tip that a group was trying to sell uranium, arrested four suspects who were found in possession of a container of radioactive cesium [probably cesium-137]. The four had been attempting to sell the cesium for $\$ 1.4$ million. A subsequent search revealed that the suspects had also stolen three other containers of cesium from the factory.

3/22/98 - LONDON SUNDAY TELEGRAPH, "Italians Break Mafia Nuclear Arms Ring," by Bruce Johnston.

A sting operation conducted by the Italian police has led to the seizure of a $10 \mathrm{~kg}$ uranium fuel rod and the arrest of 14 people implicated in a mafia nuclear weapons ring. The uranium fuel rod 
is $70 \mathrm{~cm}$ long and contains 200 grams of U-238 and 38 grams of U-235 [1], with an enrichment level of 20 percent. The rod was initially reported to have originated from the Soviet Union [2], but the stamped numbering on the outside of the bar indicate that it was in fact produced in the United States [3]. According to environmental experts investigating the incident, it is one of nine uranium fuel rods produced by the U.S. company General Atomic in 1971 for use in the Triga II research reactor in Kinshasa, Zaire (now the Democratic Republic of Congo)

Reportedly, members of the smuggling ring offered to sell components for eight nuclear missiles to the undercover agents for 200 billion lire [5]. Instead, SCICO undercover agents offered to pay 23 billion lire for a total of nine uranium fuel rods and the illicit deal was finally struck in a cafe in Rome in 2/98. Italian Finance Guards then seized the uranium rod from a warehouse. The Cosa Nostra gang reportedly obtained the uranium fuel rods after the ouster of President Mobutu from Zaire in 5/97.

[1] 3/21/98 - CORRIERE DELLA SERA (Milan), "Background to Uranium Seizure Reported;" in FBIS-WEU-98-080, 3/21/98.

[2] 3/20/98 - RAI UNO TELEVISION NETWORK (Rome), "Uranium Bar Said To Have Come From Former Soviet Arsenal;" in FBIS-WEU-98-079, 3/20/98.

[3] 3/20/98 - RAI UNO TELEVISION NETWORK (Rome), "Uranium Bar Seized in NTrafficking Gang Bust Made in US;" in FBIS-WEU-98-079, 3/20/98.

[4] 3/20/98 - ANSA (Rome), "More on Nuclear Ring; Uranium of US Origin;" in FBIS-WEU98-079, 3/20/98.

[5] 3/21/98 - LA REPUBLICA (Rome), "Agents Describe Meetings With Uranium Gang;" in FBIS-WEU-98-080, 3/21/98.

11/22/97 - Associate Press (Bucharest), "Romania Seizes \$1.5M In Uranium."

On 21 November 1997, the Romanian PRO TV television station reported that police in Bucharest, Romania arrested two Romanians and two Moldovans for attempting to sell 13.3 ounces of uranium. The police, posing as prospective buyers, met the four dealers in a downtown Bucharest restaurant. According to senior police official Constantin Marinescu, the undercover police officers arrested the dealers after they revealed five uranium tablets amounting to 3.5 ounces. According to Romanian authorities, the entire amount of uranium seized in the affair is worth approximately $\$ 1.5$ million.

\section{1/14/97 - KOMMERSANT DAILY, "Gor I Chernomyrdin Pomogli Ostanovit Khishcheniya Urana," p. 7.}

According to this article, the largest number of thefts of nuclear material in Russia have been from the Electrostal Machine-Building Plant, a nuclear fuel production facility outside of Moscow. In a recent case, three men were convicted of stealing and attempting to sell $1.7 \mathrm{~kg}$ of uranium from Electrostal. Another case involved the theft of a much larger quantity of material from the same factory. In 1993, Sergei Kopylov, a metalworker employed at the factory, diverted $115 \mathrm{~kg}$ of radioactive uranium dioxide pellets.

10/9-15/97 - OBSHCHAYA GAZETA, "Yadernaya Kontrabanda Grozit Tsepnoy Reaktsiyey," by Fedor Ryurikov, No. 40, p. 8. 
Yaroslav Vanger, a former nuclear power plant employee from Dukovani, and Aleksandr Shcherbinin, a citizen of Tajikistan, have been sentenced to eight years each in prison by a Prague city court for attempting to sell $2.7 \mathrm{~kg}$ of highly-enriched uranium (in 12/94 - ed.) Vanger and Shcherbinin reportedly had been trying to sell the uranium for $\$ 1300$ per gram, with members of the Russian mafia working as middlemen.

9/29/97 - William Potter, "Potter/Ewell Notes from Kurchatov/Semipalatinsk Conference and Excursions."

In 1995, 450 tons of beryllium was diverted and exported from the Ulba Metallurgy Plant in UstKamenogorsk, Kazakhstan. Fifty tons of that material was sent to the port of Goteborg in Sweden, where it remains to this day.

9/20/97 - KABARDINO-BALKARSKAYA PRAVDA (NALCHIK), "Sotrudniki SeveroKavkazskogo RUOP Izyato Okolo $4 \mathrm{Kg}$ Urana-238," p. 1.

On 18 September 1997, officers from the North Caucasus-branch of the Organized Crime Division of the Russian Ministry of Internal Affairs confiscated $3.8 \mathrm{~kg}$ of uranium-238 (U-238) and $2 \mathrm{~kg}$ of "(red) mercury oxide" (sic) from a criminal group operating in the cities of Ivanov, Stavropol, and Vladikavkaz. The U-238 in question was reportedly stolen in 1994 from one of the production facilities in the closed city of Arzamas-16. The isotopic composition of the material has been confirmed by the Kurchatov Institute.

9/17/97 - 9/23/97 - THE PRAGUE POST, "Uranium Smuggling Case Botched, Judge Tells Cops," by Ondrej Benda and Ross Larsen.

The Prague City Court recently completed the trial of eight people charged with peddling $2.73 \mathrm{~kg}$ of weapons-grade enriched uranium in the Czech Republic. In June 1994, the two men smuggled $2.73 \mathrm{~kg}$ of enriched uranium in metal containers onboard a train from Poland to the Czech Republic. They made several attempts to sell the uranium, originally at a price of $\$ 1,300$ per gram. Finding no buyers, they employed a "Russian group" to broker the sale of the uranium for $\$ 400$ per gram.

4/5/97 - NOVOSIBIRSKIYE NOVOSTI, "Sidite, Pazlagayete Molekuly Na Atomy?" p. 5. The West-Siberian regional police force and the Novosibirsk city police have detained seven individuals for attempting to sell $5.2 \mathrm{~kg}$ of uranium-235 for USD $\$ 100,000$. The material is believed to have originated in the Ulba Metallurgy Plant in Ust-Kamenogorsk, Kazakhstan and shipped through a transshipment base in the Russian city of Rubtsovsk, Altay region.

2/21/97 - PANORAMA, "V Ust'-Kamenogorske Zavershilsya Sudebnyy Protsess Po Delu O Khishchenii Yadernogo Topliva I Redkikh Metallov," by Vladimir Bogovitskiy. On 30 December 1996, a group of 18 individuals were sentenced to between eight and three years in prison for the theft, illegal storage and sale of nuclear materials. The individuals were responsible for the theft of $146.378 \mathrm{~kg}$ of nuclear fuel pellets and $438.694 \mathrm{~kg}$ of radioactive thorium-232 from the Ulba Metallurgy Plant in Ust-Kamenogorsk, as well as $58.28 \mathrm{~kg}$ of the highly-toxic rare-metal thallium and $19.88 \mathrm{~kg}$ of indium from the Ust-Kamenogrosk Lead-Zinc Combine. The leader of the group was P. Zenovyev, a former employee of the Ulba plant. 
12/16/96 - 24 CHASA, "Isperikh Radioactive Containers Originated `Abroad;'" in FBIS-EEU96-242, 12/16/96.

On 15 December 1996, in the northeastern Bulgarian town of Isperich, Bulgarian police seized eight containers of highly radioactive materials, including uranium, plutonium, radium, iridium, and cesium-137. Three suspects, all Bulgarian nationals, were arrested in connection with the seizure. The eight containers, weighing roughly $30 \mathrm{~kg}$, were found in the houses of the suspects. The origin of the material is still unknown.

11/23/96 - SVENSKA DAGBLADET (Stockholm), "1995 Theft of Beryllium Shipment From Arlanda;" in FBIS-WEU-96-231, 11/23/96.

In December 1995, one ton of beryllium disappeared from a freight terminal at the Arlanda airport in Sweden. The beryllium had been shipped from Russia to a port in Stockholm, after which it was scheduled to be flown to the United States from Arlanda. The shipment, which was unmarked and bore no information about the sender, was picked up at the Stockholm port on 29 December 1995 . Swedish police estimate the value of the beryllium at between roughly $\$ 90,000$ and $\$ 420,000$.

10/26/96 - NTV Moscow; in FBIS-SOV-96-209, "Chernobyl Workers Arrested Trying To Sell $5.5 \mathrm{~kg}$ Of Uranium."

A Kiev regional court, which earlier sentenced three Chernobyl plant workers to jail for stealing $5.5 \mathrm{~kg}$ of uranium from the sarcophagus, officially reprimanded Chernobyl NPP management for poor plant security. Ukrainian authorities are particularly concerned about reports that a man claiming to represent an Arab firm had contracted with the three plant workers for $100 \mathrm{~kg}$ of uranium.

10/11/96 - DELOVAYA NEDELYA (ALMA ATA), "Utechka Urana Mozhet Povlech Mezhdunarodnaya Skandala, A Utechka Informatsii - Mezhdunarodnuyu Pomoshch." On 7 December 1995, Kazakhstani special forces detained two Kazakhstani citizens in an automobile in Ust-Kamenogorsk containing $4.1 \mathrm{~kg}$ of uranium, $1 \mathrm{~kg}$ of thorium, $18.36 \mathrm{~kg}$ of indium, and $145.7 \mathrm{~kg}$ of uranium in the possession of the two men.

In a separate case, on 10 December 1995, Kazakhstani special forces discovered that 20 boxes of radioactive thorium, weighing a total of $437.6 \mathrm{~kg}$, had been stolen from the Ulba Plant. Some of the missing materials were found at the homes of Ulba workers, but some of the materials had already becn sold. These matcrials subsequently were found and confiscated by Russian Federal Security Service officials in Novosibirsk.

The third case broke on 24 March 1996 when two officials of the Main Investigative Committee of the Kazakhstan Committee for National Security discovered two workers from the Ulba Metallurgical Plant with $100 \mathrm{~kg}$ of stolen uranium-235 (sic). The material had apparently been stolen four months earlier in November 1995. [See entry for 4/5/96, AFP, "Sources Say Stocks of Uranium-235 Missing," and 5/26/96, "KARAVAN-BLITS," Metal Workers Caught With 100 $\mathrm{kg}$ Stolen Uranium-235.] 
10/8/96 - KOMSOMOLSKAYA PRAVDA, "Uran Kak Sredstvo Propitaniya," by Yelena Lashko, p. 3.

In December 1995, 7 individuals were arrested for attempting to sell $11 \mathrm{~kg}$ of "uranium-235" at the Institute of Inorganic Chemistry at Akademgorodok in Novosibirsk. The suspects had planned to sell the material for $\$ 800,000$ to a Russian buyer. The buyer has not been identified. The material consisted of fuel pellets $(5 \mathrm{~g}$ each) for nuclear power reactors, and had been produced at and acquired from the Ust-Kamenogorsk Combine in Kazakhstan.

\section{ACKNOWLEDGEMENT}

This work was performed under the auspices of the U.S. Department of Energy by Lawrence Livermore National Laboratory under contract No. W-7405-Eng-48. 